\title{
交差点付近における車イス利用者と健常者の注視特性 \\ A STUDY ON THE CHARACTERISTICS OF EYE FIXATION OF THE WHEELCHAIR USER AND GENERAL PEOPLE IN THE INTERSECTION
}

知花弘吉*

Kokichi CHIBANA

\begin{abstract}
We examined the characteristics of the eye fixation in stopping at the signal and moving . The experiment was performed at the intersection by general people and wheelchair user.The results are as follows. (1)The average time of the eye fixation is not different between them in both situation. But, when they stop at the signal, it is longer than that of the other situation. (2) The object of the eye fixation is different between them when they are moving . (3)General people can get much preceding information than wheelchair user.
\end{abstract}

Keywords : eye camera, intersection, wheelchair user, pedestrian, eye movement, eye fixation アイカメラ, 交差点, 車イス利用者, 歩行者, 眼球運動, 注視行動

\section{1.はじめに}

歩行者は空間側から何らかの情報を得て歩行を維持する.一般的 には視覚を通して得られる情報(以下, 視覚情報と称す)に依存して いる. しかしながら，歩行者がどのような視覚情報を得ているかに ついては充分に解明されているとは言いがたい：よって実際の歩行 空間での車イス利用者も含めた歩行者の視覚情報特性を明らかにす ることは, 歩行者の視点に立った, より良い環境整備を進めていく上 で重要である.

本研究は, 歩行者が実際の空間を移動する際の視覚情報をより客 観的に捉えるために,アイカメラを装着した被験者による移動実験 をおこない,得られたデー夕を基にして空間と人間の視覚的かかわ りについて，より客観的に明らかにすることを目的とする.

アイカメラを用いて注視に着目した既往研究は実験場所, 被験者 の状態の組み合わせから検討すると, 概ね, (1)屋内一静止(屋内一静 止画像, 屋内一動画), (2)屋内一移動, (3)屋外一静止, (4)屋外一移動の 4 つに分類できる. (1)で，清家ら”は面の構成要素が視野内に占 める割合や数と注視点分布への影響について, 横山ら 本となる直線通路に関するスライド提示による実験をおこない, 注 視時間について、杉山ら 33 はスライドを10秒間ずつ連続的に提示す る実験をおこない, 注視量のエントロピーについて,森保 ${ }^{4)}$ は集合住 宅の立体ファサード模型を提示して注視点の位置, まとまり感につ いて検討している．屋内て動画を用いた研究では,杉山占らは自動 車の車窓より撮影されたV T Rを屋内で提示し, 通常運転時の視点
動向について検討している. (2)ては, 生駒ら ${ }^{6)}$ は直線廊下で歩行実 験をおこない, 中所, 低所の標識の注視について, 延原ら は住宅内 で歩行実験をおこない，段差を高くすると視点停留時間が長くなる ことを指摘している. (3)では, 堀ら ${ }^{8)}$ は単木に対する実験をおこな い, 視覚パターンにはある程度共通性があること, (4)では, 田島 ${ }^{93} ら$ は夷際の歩行空間において歩行実験をおこない, 注視対象が地面, 工 ッジであること, 筆者 ${ }^{(0)}$ は眺望のよい屋外スロープにおいて車椅子 移動と通常歩行の実験をおこない, 通常歩行と車椅子移動の注視対 象が異なる傾向にあることを明らかにした。

それぞれに注視に関する研究の成果は貴重な知見を蓄積している. しかし, 移動時の注視研究は極わずかであり, 実験終了後のずれの検 討や基本的な定義をやや詳細に記述した研究は多くない. また, こ れまでの移動時における注視研究は, 自動車などによる危険性がな い安全な歩行空間(建物内の廊下なども含む)が中心であり,被験者 は健常者が主である.

本報では, 被験者を車イス生活者と健常者とし, 対象空間は歩行者 にとって安全確認が必要な交差点を選定し, 歩行は歩道を通って信 号待ちを経て横断終了までの行動(以下，行動または行動形態亡称す) を設定する，そして，両者の注視特性の違いを明らかにするために 車イス生活者の移動 (以下, 車イス移動亡称す) と健常者の通常歩行 (以下,通常歩行と称す)をおこなう(以下，両者を総称して移動また は移動形態と称す)，その結果を情報収集の時間的特性, 注視対象の 特性について分析し, 若干の考察を加える. 


\section{2. 実験の㳳要}

\section{1 実験揚所}

交差点は道路の幅員, 歩道の有無, 横断歩道の有無, 信号機の有無 等によって多種多様に分類される.これは道路の役割分担と関係す る. 交通量の多い幹線道路は歩道, 信号等が整備されているのが, 生 活道路にはそれらが設置されていないのが一般的である．本報では 幹線道路で歩道が設置され，平面交差する交差点を対象とする，交 差点には横断歩道, 自動車用, 歩行者用信号が設置されている。また, 被験者にとっては日常的に使用している場所ではない，実験場所の 概要は図1,2に示す通りである

\section{2 実監日時之被験者}

1992年と1995年の10-11月の期間に断続的に実施した，被験者を 表1に示す．健常な男子学生5名, 事故などで脊髄を損稘したために 車イス生活を余儀なくされている者5名の合計 10 名である。

\section{3 実験方法}

図2に示すように;被験者へは，出発点から横断うースを一周して 出発点に戻って来るように，出発点で指示する．他のことに関して は一切指示しなかった：注視をとらえるために角膜反射方式のアイ カメラを使用する(EMR - V 改良型 $)^{10 \sim 12)}$. アイカメラは健常者 の場合は背中に背負い，車イス移動者の場合は車イスの走行に支障 のないように，また，車イス之一体感が保てるようにするため車イス に固定する.アイカメラをスタート地点の手前で被験者に装着し， キャリブレーション用クロスバーを用いてキャリブレーションをお こない, 実験終了後にもキャリブレーション用クロスバーを用いて アイマークのずれの状況の確認亡記録をおこなう.

\section{3. 分析方法}

\section{1 分析のテータ}

アイカメラを被験者が装着しての移動実験の結果として得られる データは, 頭部の正面に設置された視野撮影ユニットから得られる 視野映像(景色の映像)とアイマーク撮影ユニットから得られるアイ マークの座標値である，両者は実験時に合成され毎秒30フレームが 携带用V T Rに録画される。後日, 実験時に録画されたビデオテー
表1 被験者リス卜

\begin{tabular}{|c|c|c|c|c|c|}
\hline \multicolumn{2}{|c|}{ 健常者 (通常齿行) } & \multicolumn{4}{|c|}{ 車イス生活者(手動車イス移動) } \\
\hline \multicolumn{2}{|c|}{1992.10} & \multicolumn{4}{|c|}{1995.10} \\
\hline 被験者 & 年跉(歳) & 被験者 & 年秢(歳) & 車イス経験(年) & 原因 \\
\hline FK & 22 & SI & 22 & 3 & 交通 事故 \\
\hline KO & 22 & $\mathrm{KI}$ & 36 & 13 & 転落 事故 \\
\hline Mo & 23 & $\mathrm{KA}$ & 48 & 18 & 祭りでの事故 \\
\hline$M I$ & 22 & NI & 38 & 14 & 物品落下事故 \\
\hline YM & 23 & YA & 32 & 15 & スポーツ事故 \\
\hline
\end{tabular}

表2 分析フレーム数とアイマークの消失率 $(\%)$

\begin{tabular}{|c|c|c|c|c|c|c|c|c|c|c|}
\hline \multicolumn{2}{|c|}{ 被験者 } & FK & & Mo & MI & $Y M$ & SI & $\mathrm{KI}$ & $\mathrm{KA}$ & $Y A$ \\
\hline 分析 & 步道上 & 340 & 375 & 305 & 365 & 435 & 340 & 402 & 395 & 461 \\
\hline $7 v-4$ & 信号待 & 1180 & 1220 & 1235 & 1430 & 1425 & 790 & 1237 & 270 & 1121 \\
\hline 数 & 横断中 & 260 & 305 & 275 & 250 & 335 & 381 & 360 & 297 & 524 \\
\hline 消失 & 歩道上 & 2 & 20 & 0 & 32 & 54 & 0 & 4 & 5 & 4 \\
\hline $7 v-4$. & 信号待 & 37 & 62 & 51 & 189 & 122 & 19 & 32 & 132 & 15 \\
\hline 数 & 横断中 & 3 & 29 & 10 & 9 & 13 & 14 & 0 & 59 & 40 \\
\hline \multirow{3}{*}{$\begin{array}{c}\text { 消 失 } \\
\text { 率 }\end{array}$} & 歩道上 & 0.6 & 5.4 & 0.0 & 8.8 & 12.4 & 0.0 & 1.0 & 1.1 & 0.9 \\
\hline & 信号待 & 3.1 & 5.1 & 4. 1 & 13.2 & 8.6 & 2.4 & 2.6 & 0.015 .4 & 1.3 \\
\hline & 横断中 & 1.2 & 9.5 & 3. 7 & 3.6 & 3. 9 & 3.7 & 0.0 & 1. $7 \quad 15.6$ & 7.7 \\
\hline 備考 & \multicolumn{4}{|c|}{ 歩道上:歩道を移動中， } & \multicolumn{3}{|c|}{ 信号待：信号待ち， } & \multicolumn{3}{|c|}{ 横断中：横断中 } \\
\hline
\end{tabular}

プに各被験者の実験開始から終了までを1フレーム毎にフレーム番 号を付す．このフレーム番号を手がかりに解析をする．また，本報 では歩道を移動中, 信号待ち, 横断中(以下，これらを行動形態と称す） を分析の対象亡する. 被験者, 分析フレーム数などは表 2 の通りであ る.

\section{2 アイマークの消失率}

アイマークは目の細さ,角膜の凸凹が激しいときの乱反射のおこ りやすさ，また，まばたきなどによって消える。このような原因でア イマークが記録されないフレーム(以下,消失フレームと称す)が生 じる.アイマークが記録されていないフレームが多くなると, 実験 結果への影響が大きくなり，実験の信頼性に疑問が残る，そこで消 失率を次式で算出してデータの信頼性について検討する。

$$
\mathrm{St}=(\mathrm{Sft} / \mathrm{Bft}) \times 100
$$

但し, St:消失率 $(\%), \mathrm{Sft}$ : 消失フレーム数の合計 $\mathrm{Bft}$ : 分析フレーム数合計

各被験者の消失率を表 $2 に$ 示す。一般的には静止画像を用いた注

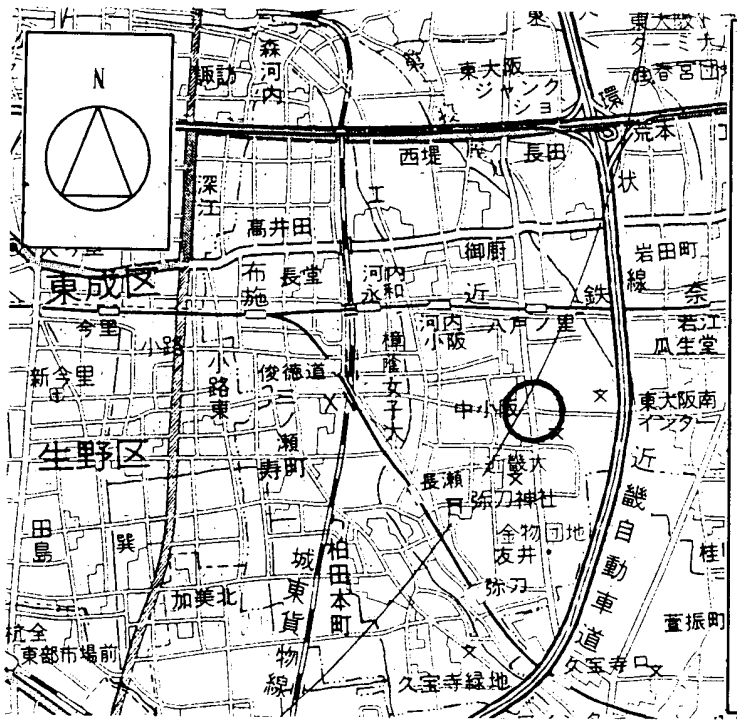

図 1 実験場所の位置

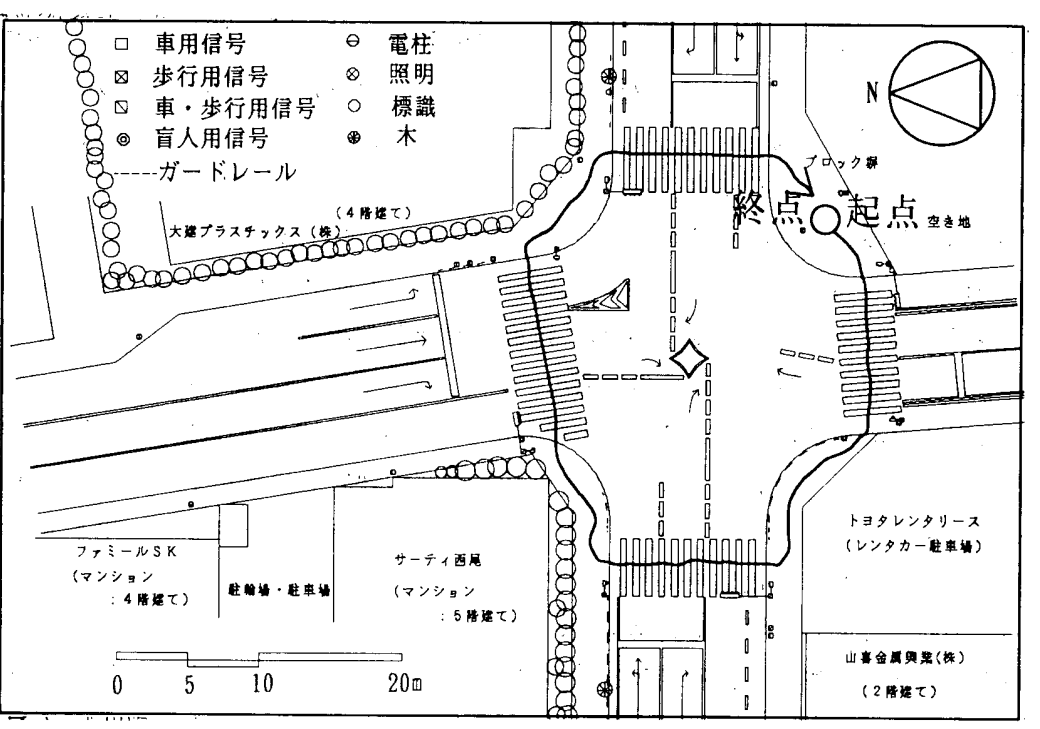

図 2 交差点の概略 
視実験ての消失率は10\%程度とされている. 足立ら ${ }^{(3)}$ にると健常 者では18.9\%,精薄者ては19.5\%, 痴呆性老人では23.7\%との報告がな されている，本実験の場合は $0 \%$ 15.6\%であるが, 概ね10\%以下であ り,解析デー夕は以下の分析にも有効である.

\section{3 停留・停留籁囲 (注視)}

アイカメラを用いた研究では停留点を抽出して解析を進めるのが 一般的である. 停留点の抽出はアイマークが停留しているとみなす 時間(以下, 停留時間之称す) と範囲(以下, 停留範囲と称す)を決めな ければならない，停留時間について渡辺ら ${ }^{14)}$ はテレビ放送画面を 用いた研究において, 内容を認識するには0.2〜0.5秒程度の停留が 必要であると報告している，既往研究でも渡辺らの報告の下限値で ある0.2秒を用いた報告がなされている2８８１0１１3）。本報において もこれらに従い下限値の0.2秒以上の視点の停留を停留時間(以下, 注視時間と称す)とする. また, 停留範囲は中心視が2. $5 \sim 3.0^{\circ}$ と推

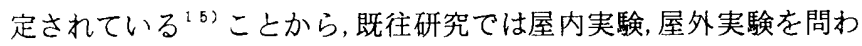
ず頭部を固定した実験においては中心简, 中心視の範囲内を基準に デー夕処理をした報告がなされている2８，16１77．歩行時の実験の 場合も中心窝, 中心視の範囲内を基準に報告されている ${ }^{6,10)}$

これらのことにより,アイマークの移動が $3^{\circ}$ 以内に，0.2秒以上停 留している場合を注視（注視点）とし, 停留している時間を注視時 間とする．また，注視点が抽出された場合のアイマーク位置にある 景色の映像のものを注視対象とする.

注視点を用いて注視時間や注視対象を求める. 注視対象物はつレ 一ム番号を手がかりにして、コマ送りによりモニター上に表示され ているアイマークの位置にある景色映像を読み取り,記録用紙に記 録する.

\section{4. 実験結果と考察}

\section{1 注視の時間的特性}

\section{1.1 分析時間における総注視時間の占める割合}

分析時間の中で注視に費やしている時間(以下，総注視時間と称す） について検討する，総注視時間とは,アイマークには記録されてい るものの注視として見なされない時間 (以下, 非注視時間と称する) 亡消失時間を, 分析時間から除外した時間であり, 次式で求める.

$$
T t=B t-(H t+S t)
$$

但 $L, T t$ : 総注視時間(秒), B $\mathrm{t}$ : 分析時間(秒),

$\mathrm{Ht}$ : 非注視時間の合計(秒), St: 消失時間の合計(秒)

総注視時間の占める割合の分布を表 3 に示す。行動形態別の平均 注視時間は移動中では通常歩行 $60 \%$ ～65\%, 車イス移動 $40 \%$ 45\%, 信号 待ちでは両者とも約70\%である. D. ノートンら ${ }^{(8)}$ によると図形に 対する総注視時間は $25 \%$ 35\%とのことである.この值よりは高い割 合であり,屋内実験とは異なる傾向が伺える.

平均值の差についての $\mathrm{t}$ 検定の結果を表 4 に示す，通常歩行では 行動形態の違いによる有意差は認められない。車イス移動では, 歩 道を移動中と横断中とには有意差は認められないものの, 信号待ち と歩道を移動中あるいは横断中とには有意差が認められる.

また, 車イス移動での信号待ちと通常歩行でのいずれの行動形態 とには有意差は認められないが, 車イス移動での歩道を移動中と横 断中は通常歩行てのいずれの行動形態とも概ね有意差が認められる.

これらのことにより,総注視時間は屋内での図形を用いた実験結
表3 分析時間における総注視時間の占める割合 $(\%)$

\begin{tabular}{l|ccccc|c|ccccc|c}
\hline \multicolumn{1}{|c|}{ 移動 } & \multicolumn{5}{|c|}{ 通常歩行 } & \multicolumn{5}{|c}{ 車イス移動 } \\
\hline 被験者 & FK & K0 & M0 & MI & YM & 平 均 & SI & KI & KA & NI & YA & 平均 \\
\hline 歩道上 & 62.0 & 65.4 & 72.4 & 49.2 & 42.9 & 59.4 & 43.7 & 41.7 & 37.1 & 70.7 & 30.2 & 44.7 \\
信号 待 5 & 61.2 & 68.0 & 76.5 & 73.5 & 74.2 & 70.7 & 73.6 & 72.3 & 75.9 & 55.2 & 68.1 & 69.0 \\
横断中 & 58.7 & 75.0 & 80.7 & 48.2 & 61.7 & 64.9 & 26.1 & 48.8 & 33.8 & 53.8 & 39.8 & 40.5 \\
\hline
\end{tabular}

表4 総注視時間の $\mathrm{t}$ 検定の結果

\begin{tabular}{|c|c|c|c|c|c|c|c|}
\hline \multirow{2}{*}{\multicolumn{2}{|c|}{$\begin{array}{l}\text { 移動形態 } \\
\text { 行動形態 }\end{array}$}} & \multicolumn{3}{|c|}{ 通常齿行 } & \multicolumn{3}{|c|}{ 車イス移動 } \\
\hline & & 歩道上 & 信号待 & 横断中 & 歩道上 & 信号待 & 横断中 \\
\hline \multirow{3}{*}{ 通常 } & 歩道上 & & - & - & - & - & $*$ \\
\hline & 信号待 & 11.3 & 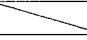 & - & $*$ & - & $*$ \\
\hline & 横断中 & 5.5 & 5.8 & S & * & - & * \\
\hline \multirow{3}{*}{ 車仅 } & 步道上 & 15.3 & 26.0 & 20.2 & & $*$ & - \\
\hline & 信号待 & 9.0 & 1.7 & 4. 1 & 24.3 & & $*$ \\
\hline & 横断中 & 19.5 & 30.2 & 24.4 & 4.2 & 28.5 & 2 \\
\hline \multicolumn{2}{|c|}{ 備 考 } & \multicolumn{6}{|c|}{ 左下：平均値の差，右上：険定結果 一：有意差なし，*：5x有意 } \\
\hline
\end{tabular}

果よりも長いことが明らかになったこれは，実際の空間を把握す るには図形の空間を把握するよりも長い時間を必要とすることを意 味している. また, 通常歩行での歩道を移動中, 信号待ち, 横断中, 車 イス移動での信号待ちの総注視時間は概ね同じであるが, 車イス移 動での歩道を移動中と横断中は，それより短い、これは, 車イスを操 作しながら移動するということの負担が総注視時間に影響している と考えられる。

\section{1. 21 注視おたりの注視時間}

注視に関する既往研究が注視時間を指標としているので,これと 比輘するために, 1 注視あたりの平均時間(以下, 平均注視時間と称 す)について検討する，平均注視時間は次式で求める.

$$
\mathrm{Htz}=\mathrm{Tt} / \mathrm{Tk}
$$

但し. $\mathrm{Htz}$ : 平均注視時間 (秒/回), $\mathrm{T} t$ : 総注視時間(秒), $\mathrm{Tk}:$ 注視回数の合計 (回)

各被験者の平均注視時間を表 $5 に$ 示す. 歩道を移動中の場合は, 通 常歩行では平均注視時間は $0.27 \sim 0.35$ 秒, 車イス移動では0.27〜0.3 7 秒である. 信号待ちの場合は, 通常歩行では0.36〜0.46秒, 車イス 移動では0. 38〜0.45秒である. 横断中の場合は, 通常歩行では0. 28 〜0.39秒, 車イス移動では0.28〜0.36秒である.

歩道を移動中, 信号待ち, 横断中のいずれにおいても平均注視時間 は通常歩行と車イス移動では同じ傾向である，一元配置による分散 分析の結果でも有意差が認められない.

既往の注視研究では, 清家ら”は静止画像ては0.2〜0.45秒, 田島 は大学キャンパスての健常歩行では0. 52秒, 筆者 ${ }^{(2)}$ は車イス生活者 の屋外平坦部移動では0.32秒などの結果を得ている.

本報の結果は移動中では0. 30〜0.33秒, 信号待ちでは0. 41 0. 43 秒である.これらは清家らの静止画像の平均注視時間 $(0.2 \sim 0.45$ 秒) の範囲内にある．移動中の場合は筆者の車イス生活者の平坦部移動 と概ね同じ値であり，田島らの結果よりは短い結果である.

次に, 個人差, 行動形態の違いに上る平均注視時間への影響を検討 するために, 移動形態別に個人差, 行動形態の違いについて二元配置 による分散分析の結果を表6に示す.

\begin{tabular}{|c|c|c|c|c|c|c|c|c|c|c|c|}
\hline 移動 & \multicolumn{5}{|c|}{ 通常歩行 } & \multicolumn{6}{|c|}{ 車イス移動 } \\
\hline 被䖒者 & FK & MO & MI & $Y M$ & 平均 & SI & $\mathrm{KI}$ & $\mathrm{KA}$ & NI & $\mathrm{YA}$ & 平均 \\
\hline 歩道上 & $\begin{array}{lll}0.35 & 0.33\end{array}$ & 0.33 & 0.30 & 0.27 & 0.32 & 0.29 & 0.28 & 0.27 & 0.37 & 0.29 & 0.30 \\
\hline 信号特 & $0.38 \quad 0.36$ & 0.48 & 0.46 & 0.38 & 0.41 & 0.45 & 0.40 & 0.45 & 0.38 & 0.45 & 0.43 \\
\hline 横断上 & 28 & & & .36 & 0.33 & 0.28 & .3 & 0.28 & 0.36 & 0.32 & 0.31 \\
\hline
\end{tabular}

表 5 平均注視時間(秒) 
表6 注視時間の分散分析の結果

\begin{tabular}{|c|c|c|c|c|c|c|c|}
\hline & 要因 & 偏差平方和 & 自由度 & 不偏分散 & F值. & 判定 & \\
\hline & 因子 A & 0.0297 & 2 & 0.0148 & 10.5779 & 0.0057 & $* *$ \\
\hline 通，常 & 因子 B & 0.0124 & 4 & 0.0031 & 2.2164 & 0.1571 & \\
\hline \multirow{2}{*}{ 歩行 } & 誤差 & 0.0122 & 8 & 0.0014 & & & \\
\hline & 全体変動 & 0.0533 & 14 & . & & & v \\
\hline 車 & 因子A & 0.0490 & 2 & 0.0245 & 16.2428 & 0.0015 & ** \\
\hline 1 2 & 因子 B & 0.0032 & 4 & 0.0008 & 0.5364 & 0.7136 & \\
\hline \multirow[t]{2}{*}{ 移 動 } & 誤差 & 0.0120 & 8 & 0.015 & & & \\
\hline & 全体変動 & 0.0644 & 14. & & - & & \\
\hline & & & & & & & \\
\hline
\end{tabular}

通常歩行と車イス移動のいずれにおいても，個人差による有意差

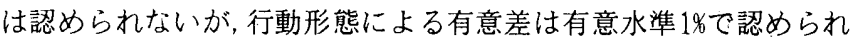
る.それは，信号待ちと歩道を移動中および横断中の場合である。

これらのことにより,平均注視時間は, 通常歩行, 車イス移動の違 いや個人差によって影響されるのではなく,行動形態の違いによっ て影響されることがわかる.. 通常歩行, 車イス移動とも移動中より も信号待ちの方が有意に長くなる。これは，通常歩行でも車イス移 動でも移動中よりは信号待ちのときの方が,より注意深くものを見 ているからであると考えられる。

\section{2. 注視対象物の特性}

\section{2.1 注視対象の種類}

注視対象は20種類に分類できる：各注視対象の回数の占める割合 を示したのが表7である: 各行動形態の違いによる注視対象の特徴 についてみると, 歩道を移動中の場合は，通常歩行では乗用車への注 視が最高で $26 \%$ である，それに対して車イス移動では，歩道への注 視が $61 \%$ を占める．信号待ちの場合は，各移動形態亡も乗用車への 注視が $30 \%$ 強である. 横断中の場合は，通常歩行では建物へは $21 \%$, 植え込みへは27\%である．これは進行方向に建物や植え込みなよ゙が あるのが大きく影響している．建物や植え込みへの注視というより は前方の注視をしているものと解釈した方が的確であろう，それに 対し車イス移動ではゼブラゾーンの注視へは $94 \%$ \%るる.

また, 注視対象を路面, 自動車, 動的, 静的, 信号, その他でまとめて みる亡,移動中の場合は，通常歩行では静的なものへの注視対象が46 \%を占めるが, 車イス移動では路面が7.2\%である．信号待ちの場合は， 自動車への注視が通常歩行では $41 \%$, 車イス移動ては $35 \%$, 信号への注 視は通常歩行で $20 \%$ 程度, 車イス移動では10\%程度であり, 通常歩行よ

表7 注視対象の分布比率 $(\%)$

\begin{tabular}{|c|c|c|c|c|c|c|c|}
\hline \multirow{2}{*}{\multicolumn{2}{|c|}{$\frac{\text { 行動形態 }}{\text { 移動形態 }}$}} & \multicolumn{2}{|c|}{ 齿道上 } & \multicolumn{2}{|c|}{ 信号待 } & \multicolumn{2}{|c|}{ 横断.中 } \\
\hline & & 通常 & 車人不 & 通常 & 車イス & 通常 & 車イス \\
\hline & $\begin{array}{l}\text { 歩道 } \\
\text { 車道 } \\
\text { ぜブう }\end{array}$ & $\begin{array}{l:l}7.5 & \\
2.8 & \\
2.8 & 13.3 \\
\end{array}$ & \begin{tabular}{|r:l}
50.6 & \\
5.1 & \\
5.1 & 71.7 \\
\end{tabular} & $\begin{array}{l:l}1.8 & \\
8.8 & \\
4.0 & 14.7 \\
\end{array}$ & $\begin{array}{r}1.8 \\
10.3 \\
8.5 \\
0.20 .6 \\
\end{array}$ & $\begin{array}{r:r}8.5 & \\
3.2 & \\
10.0 & 21.3 \\
\end{array}$ & $\begin{array}{l:l}23.2 & \\
22.0 & \\
48.8 & 93.9 \\
\end{array}$ \\
\hline 車 & $\begin{array}{l}n^{\circ} \text { '類 } \\
\text { 乗用車 }\end{array}$ & $\begin{array}{r}3.8 \\
25.7 \\
25.5 \\
\end{array}$ & $\begin{array}{r:l}- & \\
10.1 & 10.1 \\
\end{array}$ & $\begin{array}{|c:c|}9.1 & \\
31.8 & 40.9 \\
\end{array}$ & $\begin{array}{rll}2.7 & \\
32.7 & 35.4 \\
\end{array}$ & $\begin{array}{l:l}2.1 & \\
3.2 & 5.3 \\
\end{array}$ & \\
\hline 動 & $\begin{array}{l}\text { バイク } \\
\text { 自転車 } \\
\text { 通行人 }\end{array}$ & $\begin{array}{l:l}1.9 & \\
1.9 & \\
4.8 & 8.5 \\
\end{array}$ & $\begin{array}{l:l}- & \\
1.0 & \\
3.0 & 4.0 \\
\end{array}$ & $\begin{array}{l:l}0.8 & \\
2.1 & \\
3.2 & 5.1 \\
\end{array}$ & \begin{tabular}{|l:l|l|}
0.9 & \\
0.9 & \\
3.1 & 4.9 \\
\end{tabular} & $\begin{array}{l:l}- & \\
3.2 & \\
- & 3.2\end{array}$ & \\
\hline 的 & 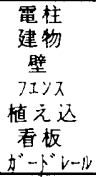 & $\begin{array}{|c:c|}10.5 & \\
12.4 & \\
- & \\
5.7 & \\
11.4 & \\
4.8 & \\
1.0 & 45.7 \\
\end{array}$ & $\begin{array}{l:l}1.0 & \\
1.0 & \\
4.0 & \\
3.0 & \\
- & \\
2.0 & 011.1 \\
\end{array}$ & $\begin{array}{c:c}2.9 \\
10.7 \\
0.8 \\
-8.8 \\
4.8 \\
-\quad & \\
- & 19.3 \\
\end{array}$ & $\begin{array}{|r:c|}7.5 & \\
12.6 & \\
- & \\
- & \\
7.2 & \\
0.9 & \\
2.2 & 30.5 \\
\end{array}$ & $\begin{array}{r:}8.5 \\
21.3 \\
1.1 \\
-15 \\
25.5 \\
1.1 \\
-\quad 51.7 \\
\end{array}$ & $\begin{array}{l:l}- & \\
- & \\
- & \\
- & \\
3.7 & \\
- & \\
2.4 & 5.1\end{array}$ \\
\hline $\begin{array}{l}\text { 信 } \\
\text { 号 }\end{array}$ & \begin{tabular}{l|l} 
歩 & $\begin{array}{l}\text { 赤 } \\
\text { 行 } \\
\text { 青 }\end{array}$ \\
車 & 赤 \\
用 & 青 \\
\end{tabular} & \begin{tabular}{|l:l} 
& \\
1.0 & \\
& \\
1.0 & 2.0 .0 \\
\end{tabular} & 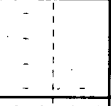 & \begin{tabular}{l:l|}
3.5 & \\
0.3 & \\
6.4 & \\
8.5 & 18.7 \\
\end{tabular} & $\begin{array}{r:c}8.5 & \\
- & \ddots \\
- & \\
-\quad & 8.5 \\
\end{array}$ & $\begin{array}{l:l}2.1 & \\
5.4 & \\
-\quad & \\
-\quad & 8.6 \\
\end{array}$ & $\begin{array}{l:l}- & 1 \\
- & \\
- & 1 \\
- & 1 \\
\end{array}$ \\
\hline$\sum 0$ & D他 & $-1-$ & 3.013 .0 & \begin{tabular}{l:l|l}
0.3 & 0.3 \\
\end{tabular} & $\begin{array}{l}-1 \\
-1\end{array}$ & $-1-$ & -1 \\
\hline
\end{tabular}

りも車イス移動の方の比率が低くなっている，通常歩行では車両用 信号への注視もあるが, 車イス移動では歩行者信号のみで車両用信号 への注視は観察されていない.

ノンパラメトリック検定法のWilcoxon検定の結果,,歩道を移動中 の場合は, 通常歩行と車イス移動の注視対象には有意水準5\%で有意 差が認められるが，信号待ちや横断中の場合は，それらには有意差が 認められない，表7でみると，信号待ちの場合は，各移動形態とも自 動車への注視が主であり，同じ傾向が読める，横断中の場合は，通常 歩行では静的対象が主であるのに対して, 車イス移動では路面が主 である傾向にあるものの, 有意差が認められないのは, 車イス移動で は注視対象の種類が少ないことが影響しているものと考えられる.

これらのことにより，移動中の場合は，通常歩行での注視対象は分 散的であるのに対して，車イス移動では路面が主な注視対象である ことがわかる.これは車イス移動での移動中の注視対象は視点の高 さや車イスを操作することの負担が影響しているからであると考え られる.また, 信号待ちの場合は, 通常歩行; 車イス移動に関わらず, 注視対象は自動車などの移動物が中心である.

\section{2.2 这視対象の分布亡距離}

注視対象の分布範囲亡距離を, 歩道を移動中, 信号待ち, 横断中に つて検討する.

まず,移動形態, 行動形態別の注視対象の分布状況を図3に示す. 歩道を移動中の場合は, 通常歩行の注視対象は進行方向へ広く分

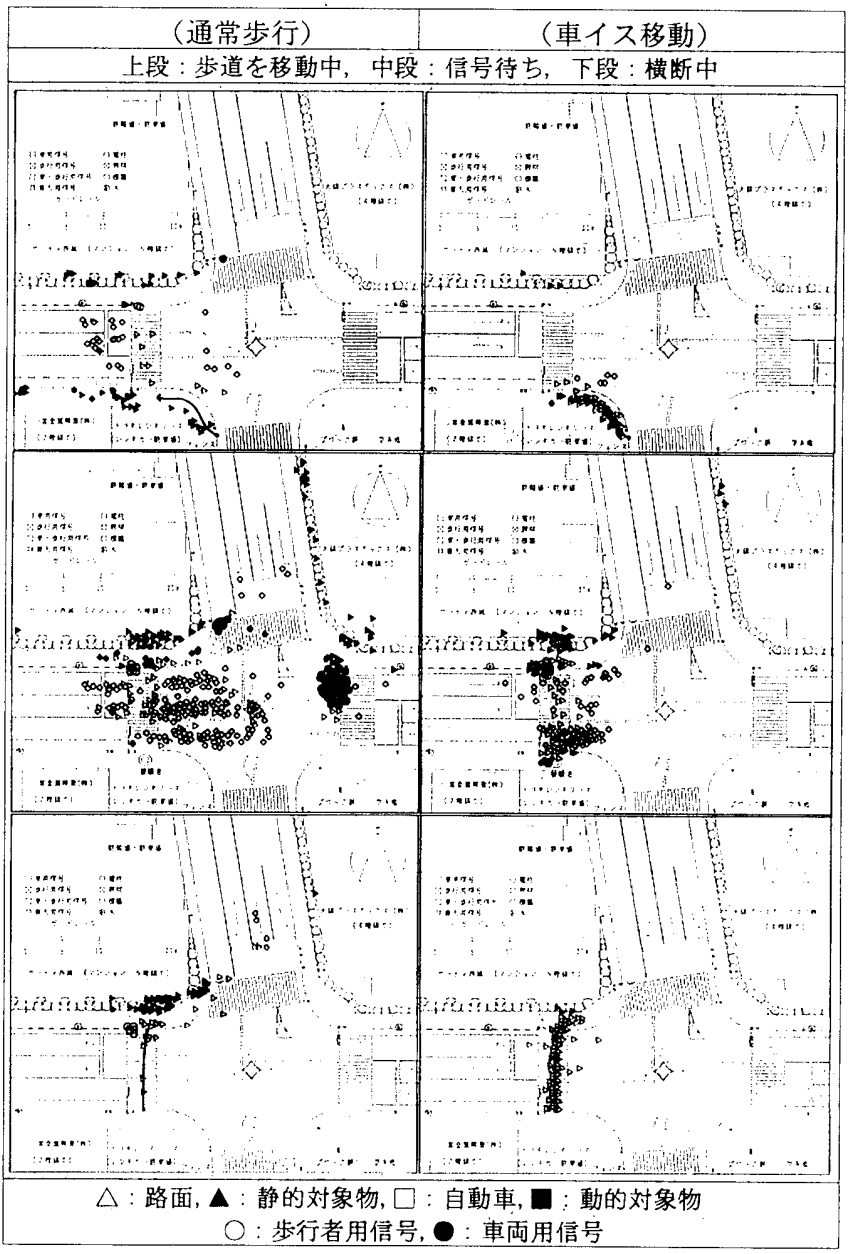

図3 注視点の分布 
表8 平均注視対象距離 $(\mathrm{m})$

\begin{tabular}{|c|c|c|c|c|c|c|c|c|c|c|c|}
\hline \multirow{3}{*}{\multicolumn{2}{|c|}{$\begin{array}{c}\text { 注視 } \\
\text { 㸚象 } \\
\text { 移動 }\end{array}$}} & \multirow{3}{*}{ 路 } & \multirow{3}{*}{$\begin{array}{l}\text { 自 } \\
\text { 動 } \\
\text { 車 } \\
\end{array}$} & \multirow{3}{*}{ 動 } & \multirow{3}{*}{$\begin{array}{l}\text { 静 } \\
\text { 的 }\end{array}$} & \multicolumn{4}{|c|}{ 信号 } & \multirow{3}{*}{$\begin{array}{l}\text { そ } \\
の \\
\text { 他 } \\
\end{array}$} & \multirow{3}{*}{ 平均 } \\
\hline & & & & & & \multicolumn{2}{|c|}{ 歩行者用 } & \multicolumn{2}{|c|}{ 車両用 } & & \\
\hline & & & & & & 赤 & 青 & 赤 & 青 & & \\
\hline 步道 & $\begin{array}{l}\text { 通常 } \\
\text { 車1 }\end{array}$ & $\begin{array}{l}4.0 \\
3.6 \\
\end{array}$ & $\begin{array}{l}9.7 \\
5.4\end{array}$ & $\begin{array}{r}7.8 \\
6.4 \\
\end{array}$ & $\begin{array}{l}8.9 \\
9.1 \\
\end{array}$ & $\begin{array}{r}13.0 \\
-\end{array}$ & - & $\begin{array}{l} \\
- \\
\end{array}$ & $\begin{array}{c}12.0 \\
-\end{array}$ & 3. & $\begin{array}{l}8.2 \\
5.5 \\
\end{array}$ \\
\hline 傮号 & $\begin{array}{l}\text { 通常 } \\
\text { 車仅 }\end{array}$ & $\begin{array}{l}6.9 \\
5.1\end{array}$ & $\begin{array}{l}5.7 \\
6.3 \\
\end{array}$ & $\begin{array}{l}8.1 \\
5.7\end{array}$ & $\begin{array}{l}13.1 \\
11.4\end{array}$ & $\begin{array}{l}11.0 \\
11.0\end{array}$ & $\begin{array}{c}11.0 \\
- \\
\end{array}$ & $\begin{array}{c}17.0 \\
-\end{array}$ & $\begin{array}{r}17.0 \\
- \\
\end{array}$ & $\begin{array}{r}10.0 \\
- \\
\end{array}$ & $\begin{array}{r}11.0 \\
7.8 \\
\end{array}$ \\
\hline 横断 & $\begin{array}{l}\text { 通常 } \\
\text { 車亿 }\end{array}$ & $\begin{array}{l}5.8 \\
1.8\end{array}$ & 16.3 & 3.8 & $\begin{array}{l}6.2 \\
8.0\end{array}$ & 11.0 & $\begin{array}{c}11.0 \\
-\end{array}$ & - & - & - & $\begin{array}{l}8.0 \\
4.9 \\
\end{array}$ \\
\hline
\end{tabular}

布するが, 車イス移動では移動している場所のごく身近に分布する.

信号待ちの場合は, 通常歩行の注視対象は, 交差点一帯に広く分布 するが, 車イス移動ではその範囲が狭い，例えば, 東側の車両用信号 への注視は, 通常歩行ては多いが, 車イス移動では全くない，歩行者 用信号への注視は，通常歩行よりも車イス移動の方が若干多い，自 動車への注視は, 通常歩行では交差点の中央にまで広がるが, 車イス 移動では目前の狭い範囲である.

横断中の場合は, 通常歩行の注視対象は進行方向の路面や静止対 象であるが, 車イス移動では歩道を移動中と同様に, 目前の対象を注 視する傾向にある.

次に, 注視対象の分布範囲における注視対象までの距離(以下，注 視対象距離と称す)を計測し, その平均注視対象距離を表8に示す.

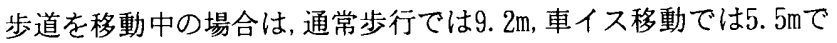
ある. 信号待ちの場合は, 通常歩行では $11 \mathrm{~m}$, 車イス移動では7. $9 \mathrm{~m} て ゙$ ある. 横断中の場合は, 通常歩行では9m, 車イス移動では4.9mてある.

車イス移動での移動中の值は, 筆者 ${ }^{18)}$ が建物へアプローチするた めの空間の平坦部における車イス移動ての值6m之概ね同じである. 各行動形態においても平均注視対象距離は車イス移動よりも通常歩 行の方が長い。つまり, 通常歩行では, 車イス移動に比べて注視対象 は進行方向や交差点一带に広く分布し，平均注視対象距離も長い傾 向にあるといえよう.

これらのことにより,通常歩行の方がこれからよ゙のように行動す るかを準備する助けとなる情報（以下，先行情報と称す)をより早く 得ようとしているといえる.

\section{3 注視対象と注視時間の特性}

注視対象別の注視時間比率および平均注視時間について検討する. 各注視対象に対する注視時間比率を表 9 に示す.

赤木ら ${ }^{19)}$ は8 $8 \mathrm{~mm}$ 映写機を用いての交差点画像に対する注視時間比 率を情報量が少ない場合, 中間的, 多い場合について検討している.

表9 注視対象と注視時間の比率 $(\%)$

\begin{tabular}{|c|c|c|c|c|c|c|}
\hline 行動形熊 & 移動形態 & 路面 & 自動車 & 動的 & 静的 & 信号 \\
\hline \multirow{2}{*}{ 歩道を移動中 } & 通常步行 & 11.8 & 25.6 & 13.5 & 47.0 & 2.2 \\
\hline & 車仅移動 & 71.6 & 12.2 & 4.0 & 9.6 & - \\
\hline \multirow{2}{*}{ 信号 待 5} & 通常步行 & 14.8 & 36.4 & 5.7 & 22.7 & 20.2 \\
\hline & 車仅移動 & 25.8 & 33.2 & 5. 7 & 26.7 & 8.5 \\
\hline \multirow{2}{*}{ 横 断 中 } & 通常歩行 & 22.2 & 3.5 & 2.3 & 63.6 & 8.4 \\
\hline & 車仅移動 & 94.6 & - & - & 5.4 & - \\
\hline
\end{tabular}

表10 注視対象と平均注視時間 $(\mathrm{Sec})$

\begin{tabular}{|c|c|c|c|c|c|c|}
\hline \multicolumn{2}{|c|}{ 注視対象 } & 路面 & 自動車 & 動的 & 静的 & 信号 \\
\hline 歩道を移動中 & $\begin{array}{l}\text { 通常步行 } \\
\text { 車仅移動 }\end{array}$ & $\begin{array}{l}0.29 \\
0.33\end{array}$ & $\begin{array}{l}0.27 \\
0.43\end{array}$ & $\begin{array}{l}0.41 \\
0.28\end{array}$ & $\begin{array}{l}0.31 \\
0.29\end{array}$ & 0.24 \\
\hline 信号待 5 & $\begin{array}{l}\text { 通常步行 } \\
\text { 車仅移動 }\end{array}$ & $\begin{array}{l}0.39 \\
0.51\end{array}$ & $\begin{array}{l}0.38 \\
0.42\end{array}$ & $\begin{array}{l}0.44 \\
0.41\end{array}$ & $\begin{array}{l}0.43 \\
0.34\end{array}$ & $\begin{array}{l}0.42 \\
0.38\end{array}$ \\
\hline 横 断 中 & $\begin{array}{l}\text { 通常歩行 } \\
\text { 車仅移動 }\end{array}$ & $\begin{array}{l}0.30 \\
0.33 \\
\end{array}$ & $\begin{array}{l}0.21 \\
-\end{array}$ & $\begin{array}{l}0.25 \\
-\end{array}$ & $\begin{array}{l}0.33 \\
0.28 \\
\end{array}$ & $\begin{array}{c}0.30 \\
-\end{array}$ \\
\hline
\end{tabular}

表11 注視対象別平均注視時間の分散分析の結果

\begin{tabular}{l|cccccc}
\hline \multicolumn{1}{c|}{ 要因 } & 偏差平方和 & 自由度 & 不偏分散 & F 值 & P 值 & 判定 \\
\hline 因子 & 0.0037 & 5 & 0.000 & 0.1436 & 0.9639 & - \\
誤差 & 0.1355 & 20 & 0.0065 & & & \\
全体変動 & 0.1393 & 25 & & & & \\
\hline \multicolumn{1}{|c|}{ 備 考 } & 因子: 注視对象 & 一: 有意差なし & & & \\
\hline
\end{tabular}

その結果によると，健常者では，車と人への注視は54\%,73\%,62\%, 静止 対象へは15\%,15\%,25\%,信号へは30\%,12\%,10\%である.

本報では，通常歩行，車イス移動の信号待ちでは，自動車，バ仿，自 転車, 人への注視は $42 \%, 39 \%$, 路面, 静的対象へは $38 \%, 53 \%$, 信号へは 20 \%,10\%である.

静的対象への注視比率は異なる傾向にあるが, 車などの動的対象 や信号に対する注視比率は概ね同じ傾向である

各注視対象の平均注視時間を表10に示す。路面へは0.43秒，自動 車へは0.34秒,動的対象へは0.36秒. 静的対象へは0.33秒, 信号へは 0.34秒であり, 路面への平均注視時間が若干長くなる. 一元配置の 分散分析の結果を表11に示す．注視対象の違いによる有意差は認め られない。

注視対象と平均注視時間については村田 ${ }^{20)}$ が整理して示してい る. それによると, 幾何学模様, 絵画, 写真などでは0.26〜0.33秒, テ レビジョンドラマなどでは0. 33 0.49秒, 高速道路走行では0.21〜0. 23秒である. 小林ら ${ }^{21)}$ によると運転者で路面, レーンマークては0. 2 秒, 追越し車両では0.41秒, 警戒・規制標識では0.42秒, 足立ら ${ }^{6)}$ よると健常者の動的誘導情報への注視は0.38秒とされている.

本報で得られた0.33〜0.43秒はテレビジョンドラマ, 追越し車両,

警戒・規制標識, 健常者の誘導情報への平均注視時間と概ね同じて ある. テレビジョンドラマ, 追い越し車両, 標識などは注意深く見な ければならない対象物であると考えられるので, 交差点付近では注 意深く情報を収集しているといえる.

これらのことにより,交差点付近での注視対象による平均注視時 間は, どの注視対象に対してもはぼ安定した注視をしていて, 注意深 く情報を収集していることが明らかになった。

\section{5. おわりに}

交差点における行動形態と移動形態の違いと注視の関わりについ て、基礎的分析をした結果，つぎのようにまとめられる.

（1）歩行を維持するために空間から得る視覚情報のうち注視の占 める時間は, 移動中では通常歩行 $60 \%$ 65\%, 車イス移動 $40 \% \sim 45 \%$, 信 号待ちでは両者とも70\%である.

(2) 平均注視時間には個人差は認められないが,移動中であるか 信号待ちであるかの影響を受ける. 移動中よりも信号待ちの方が平 均注視時間は長くなる。

（3）注視対象は移動中は通常歩行と車イス移動では異なる傾向に ある。しかし, 信号待ちの場合には有意な差は認められない.

（4）通常歩行では，車イス移動に比べて，広い範囲からより早く 先行情報を得ようとする傾向にある.

（5）平均注視時間は, 注視対象の種類による違いは認められない.

アイカメラを用いての屋外空間における歩行時の研究はこれまて ごくわずかであるため，屋外歩行時の基本的な注視特性について解 析をおこなった，本報はアイカメラを装着しているという限定のも 
とではあるが，実際の交差点における通常歩行と車イス移動の時間 的特性, 注視対象の特性について客観的に把握することができた亡 考える.

本報では; 実験を屋外空間において実施しているが, 得られた結果 の一部は地下街や京都駅のように巨大化する建築的空間における案 内・誘導のための情報などの表示や配置をする場合に応用できる可 能性が見いだせる.

たとえば, 移動中の場合, 車イス移動では路面への注視がその主な ものであることから，案内・誘導のための先行情報として天井など の上部に設置することも大切であるが, それに加えて床などのよう な低位部分にも案内・誘導のための情報を設置することが, 車イス 利用者も含めた歩行者に対してより有効な情報提供になることを示 唆しているものと考えられる

\section{今後の課題}

本報で得られた結果を踏まえて視覚情報と建築的空間との関係， さらに，建築的空間における初期的な視覚情報之空間把握との関係 なよ゙,より詳細に検討していくことが今後の課題であると考える. 具体的には高齢者や聴覚障害者など被験者の拡大, 対象空間の拡大, 建築計画上の留意点などについて定量的に明らかにしていくことて あると考える。

本研究を進めるにあたっては（社)大阪脊餚損傷者協会の協力を 得たこと,また, 研究の一部は文部省科学研究費補助金 (課題番号 07650726 ）によりおこなわれたこよ,さらに, 実験, 整理にあたって は近畿大学建築計画第 2 研究室の諸氏の協力があったことをここに 記して感謝の意を表します。

\section{参考文献}

1). 清家清, 福島駿介：建築における視覚環境の研究一アイカメラ を用いた実験的研究一, 日本建築学会学術講演梗概集, pp. 355$356,1969,8$

2). 横山友一, 荒木兵一郎, 足立啓：直線通路画像における注視状況 一痴呆性老人と精神薄弱者の視覚情報探索行動について その 5 -, 日本建築学 会学術講演梗概集, pp. 647-648, 1990.10

3). 杉山俊一, 西野真知子, 志水英樹, 鈴木信弘: アイマーク・レコ 一ダによる街路空間構造に関する研究 その1, 日本建築学会 学術講演梗概集, pp. 729-730, 1991.9

4). 森保洋之: 集合住宅形態の視知覚把握に関する建築計画的研究 一その 1 広島基町高層住宅型ファサード・モデル形態亡視知 賞的把握の特性について一, 日本建築学会計画系論文報告集, 第 410 号, pp. 53-63, 1990. 3

5). 杉山俊一, 志水英樹, 西野真知子：自動車からみた街並みの認知 構造について・その 1 , 日本建築学会学術講演梗概集, pp. 839$840,1990.10$
6). 足立啓, 荒木兵一郎：屋内歩行時の視覚誘導情報への疾呆性老 人之精神薄弱者の注視に関する研究, 日本建築学会計画系論文 報告集第439号, pp. 55-63, 1992.9

7). 延原理恵, 宮野道雄, 土井正, 立入理恵子 : 段差の視認性に関す る研究一歩行時の眼球運動一, 日本建築学会学術講演梗概集, pp. 773-774, 1996. 10

8). 堀透, 藤井英二郎, 安蒜俊比古, 浅野二郎 : 配植計画に関する基 礎的研究一単木に対する視覚パ夕ーンの解析一, 較造園雑誌, 46 (1), pp. 13-18, 1982. 1

9). 田島学, 朝倉博樹 : アイマーク・レコーダによる歩行者の注視 特性に関する基磼的研究, 日本都市計画学会, 第18回学術研究発 表会論文集, pp.151-156. 1983

10). 知花弘吉 : 眺望のよい屋外スロープにおける車椅子移動上通常 歩行の注視特性, ランドスケープ研究, VOL. 59 N0. 5, pp. 153-156 1996.5

11). 知花弘吉 : スロープでの車椅子使用時の注視について, 日本建 築学会学術講演梗概集, pp. 947-948, 1992.8

12). 知花弘吉：建物へアプローチするための空間における車イス生 活者の注視行動, ランドスケープ研究, VOL. 60 N0.5, pp. 629-632 1997.5

13）. 足立啓, 荒木兵一郎：動的誘導情報に対する注視特性の検討 痴呆性老人之精神薄弱者の視覚情報探索行動に関する研究 第 2報，日本建築学会計画系論文報告集第447号, pp.43-49, 1993.5

14). 渡辺僦, 渡辺絹二, 畑中伸典, 田中聡行: 画像亡注視点分布, NHK 技術研究, Yol1, 17, No. 1, 通巻86号; pp. 4-20, 1965

15). 岩佐靖典, 前田充, 渡辺絹二 : 視野制限下における図形・文字 文章の認識, 電気通信学会研究会, MBE84-95, pp. 93-102, 1985

16). 足立 啓, 荒木兵一郎：図形特質に対する注視傾向 痴呆性老 人と精神薄弱者の視覚情報探索行動に関する研究 第 1 報, 日 本建築学会計画系論文報告集第392号, pp. 52-59, 1988. 10

17). 川村三郎, 西名大作, 植木雅浩 : 河川景観の画像特徵量亡被験者 注視点の関連, 日本建築学会計画系論文報告集, 第479号, pp. 67 76, 1996. 1

18). D. ノートン / L スターク : 眼球運動と視覚, 別冊サイエン スー特集視賞の心理学 イメージの世界ー,pp. 97-107, 1978

19). 赤木徹也, 荒木兵一, 足立啓 : 交差点画像に対する注視状況 痴 呆性老人之精神薄弱者の視覚情報探索行動について その6, 日 本建築学会大会講演梗概集, pp. 649-650,1980.10

20). 村田隆裕：注視行動の統計的性質, 土木学会論文報告集, 第213 号, pp. 55-63, 1973.5

21). 小林実, 村田隆裕, 巻上安爾 : 高速道路工事区間での注視点調査, 交通工学, VOL. 7 増刊号, pp. 17-26, 1972

(1998年1月 8 日原稿受理，1998年３月５日採用汏䇥） 